\title{
Optimization and diversification of natural gas supply in Ukraine
}

\author{
Vadim Tkachuk ${ }^{1}$, Andriy Skrypnyk ${ }^{2}$, Viktoriia Baidala ${ }^{3}$, Nataliia Klymenko ${ }^{2}$, Yuriy \\ Namiasenko ${ }^{2}$ \\ ${ }^{1}$ Department of Labour Economics and Social Development, Faculty of Economics, National \\ University of Life and Environmental Sciences of Ukraine, Heroiv Oborony 11, 03041, Kyiv, Ukraine \\ ${ }^{2}$ Department of Economic Cybernetics, National University of Life and Environmental Sciences of \\ Ukraine, Heroiv Oborony 16, 03041, Kyiv, Ukraine \\ ${ }^{3}$ Department of Economic Theory, National University of Life and Environmental sciences of Ukraine, \\ 03041, Kyiv, Ukraine
}

\begin{abstract}
This article considers different variants of natural gas supply in Ukraine which are based on the main tendencies of natural gas regional markets and some important factors, such as: possibility to use natural gas storage system, different changes in government regulation and innovations in the energy generation and supply sphere. The purpose of this work is to substantiate the current gas supply strategy in Ukraine on the basis of quantitative methods. The main results of the article are: Numerical estimation of the positive effect, gained from the using of natural gas storage system; Numerical estimation of the positive effect from the diversification of the natural gas supply in Ukraine in terms of decreasing the potential role of Gazprom monopoly. The population response evaluation on the gas price rising. This article provides an effective tool for assessing the possible consequences of decisions of state bodies when moving away from the existing monopoly of gas supply system and the macroeconomic effect of different gas supply options. The quantitative assessment of the gradual convergence of regional markets and the creation of a global natural gas market is proposed
\end{abstract}

\section{Introduction}

Nowadays it became quite clear that very optimistic forecasts about reaching $20 \%$ of the renewable energy mark in the Ukraine total energy consumption by 2020 . If we consider three main components of renewable energy: bioenergy, solar and wind energy then primary hopes in "Energy strategy of Ukraine to 2035" have been laid on bioenergy. The reason for such kind of forecasts was an overestimation of bioenergy raw materials volumes which are formed during agrarian production. But this way requires [1] billions of investments in creating an appropriate infrastructure (technology, qualified staff, transport) [2]. Despite of the increasing interest to renewable energy, the natural gas still remains the main source of heating and electricity production even in the European countries [3,4,5].

\footnotetext{
* Corresponding author: vadtkachuk@hotmail.com
} 
Apart from this, a significant negative impact on Ukrainian bioenergy development has the cost of efficient bio energy generators, the lowest price of which approximately equals 1 million USD [6], due to the greater financial availability of solar energy, the pace of its development turned out to be significantly higher [7]. This means that only big agrarian companies can afford purchasing of them. Also tariffs of renewable energy have a significant impact on choosing a type of energy generation [8].

As a result, the rate of renewable energy growth in Ukraine is extremely low. The state of Ukrainian traditional energy is rather critical $[8,9]$. Nuclear generation provides more than $50 \%$ of total consumed energy but it consists primarily of reactors which have age of 30 years (30 years is an upper time limit of operating period). After modernization any reactor can safely work for only 10 years. It should be noticed that despite the conducted modernization of nuclear energy equipment with aging the probability of incidents is increasing [10], [11].

The solution of this problem is also rising up the level of traditional energy generation efficiency (which also provides the reduction of environmental pollution) $[12,13]$.

Considering all above mentioned, the natural gas supply in Ukraine still is on the top of energy development agenda including the diversification of gas supply to Ukraine.

This work shows that natural gas supply diversification leads to reducing overall costs, approximately on $5-10 \%$. The significant disadvantage of this work was not taking into account existing underground gas storage facilities in Ukraine, the total volume of which equals 30 billion of cubic meters [9, 14]. At this time all storage facilities are used only on $40 \%$ of their entire capacity. Significant seasonal price fluctuations which exist on different regional gas markets [15] suggest that using of natural gas storage system can have enormous economic effects. Despite the fact that Black Sea is closed for liquid natural gas (LNG) carriers it would be also useful to estimate the possible economic benefits of natural gas supply from one of the biggest global LNG supplier Qatar [16] to Black Sea ports of Ukraine. The great interest of researchers causes the question of global natural gas market formation.

Researchers' views on the problem of global natural gas formation differ significantly. Most of them insist that there is some stable tendency toward global gas market formation due to the development of innovative technologies for extraction and transportation of natural gas. Looking back to 2009, the first hypotheses about globalization of natural gas markets to the level of intercontinental trade and significant integration of the market prices were put forward [17,18]. A hypothesis about possible natural gas markets integration due to increasing volumes of LNG trade across the Atlantic Ocean basin was proposed. LNG is also considered as one of the main factors which have a great impact on natural gas price formation [19].

There were also some attempts to model the European natural gas markets in form of a two-stage game [20]. By using nonlinear optimization, the main result of the research: biggest supplier of natural gas in Europe - Russia, continues to lose its market share, while the share of liquefied natural gas import from different countries continues to growth.

The basic model of global natural gas market carries out optimization of the future productive, transport and storage capacities [21]. Besides the pipeline transportation of natural gas, the potential transportation of LNG was also taken into account. The given model allows additionally to model strategic behaviour of different players in the market (for example, the behaviour of producers).

It was proved that European natural gas market is characterized by oligopolistic supply structure which consists mainly from external suppliers herewith the capacity of transport infrastructure (pipelines and storage facilities) has a key role during determination of trade flows.

The results of modelling show a large inverse influence of the distance factor on the import volumes of pipelined and liquefied natural gas [22]. At the same time, importers on the liquefied natural gas market are characterized by large capacity of storage facilities, what 
can't be said about the European natural gas market which highly dependents on the pipeline supply system.

\section{Materials and methods}

Natural gas has always been one of the main sources of primary energy consumption in Ukraine. At this time, it takes the second place after nuclear energy. Although the growth of energy efficiency is extremely slow some positive vibes can be observed and it has impact on reducing power consumption. The same impact on total power consumption reducing has the transition of Crimea and some parts of Donetsk and Luhansk regions under control of Russia. This effect is also exacerbated by the local economic crisis of the recent years (Fig.1).

In the dynamics of gas consumption (which consists of two components: consumption by the population and industry) during global economic crisis 2008-2009 a change of ranks appeared: consumption by the population has started steadily exceed consumption by industry.

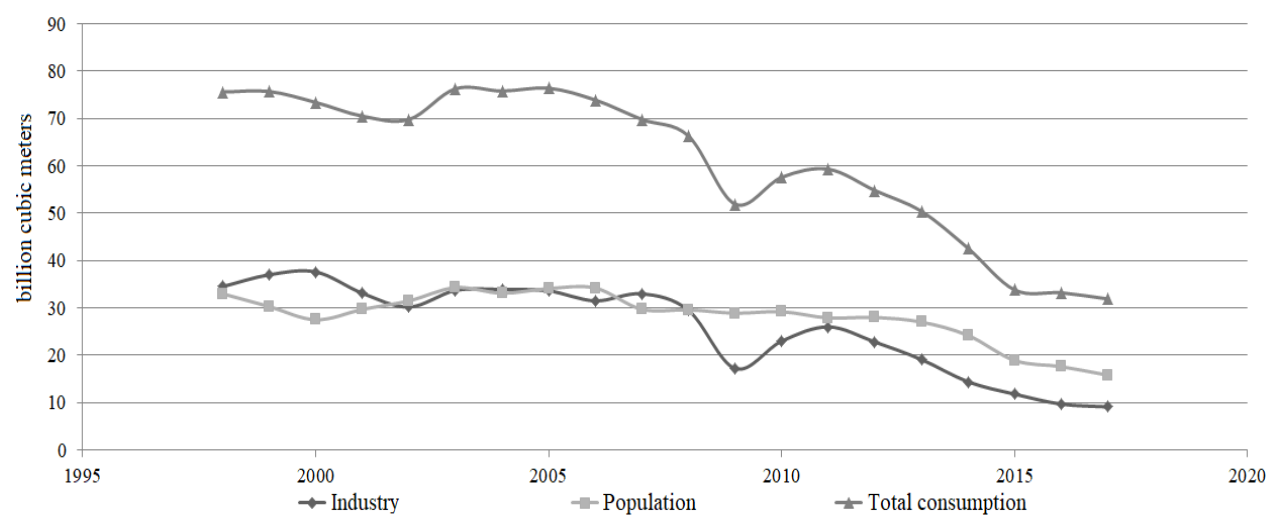

Fig.1. Natural gas consumption by industry and population in Ukraine, 1998-2017

At this it becomes quite hard to forecast whether this tendency toward natural gas consumption decreasing will be taking place in the future or not. In our opinion, there are some signs of natural gas consumption stabilizing at the estimated level of 30-32 billion cubic meters. But newly announced intent to raise the natural gas price by government in 20202021 may lead to significant reduction of gas consumption by the population.

It is known that Ukraine has at its disposal many gas storage facilities of considerable volumes, which all together can store almost the equivalent of an average annual consumption. Therefore, it is a question of large interest how the including of gas storage factor in the optimization problem will affect the total natural gas supply expenditure. Taking into consideration climatic conditions of Ukraine it should be noted that gas storage facilities in general work as consumption regions during summer season and as supply regions during winter season.

Using of gas storage facilities is also stipulated by the existing difference in spot and futures prices during winter and summer periods. The influence of seasonality and the seasonal variation on a price level was estimated by a two-factor model [14]. This model used the weekly price observations of the Henry Hub natural gas contracts.

Using available data with regard to seasonal price variation on Henry Hub it became possible to measure the price variability per 1 thousand cubic meters (common measuring of natural gas volumes in Eastern Europe region). Natural logarithm for the price of 1 (one million British Thermal Units) MMBtu during summer period equals 1.57 and during winter period equals 1.68. This means that summer price of 1 MMBtu equals 4.8 USD for the Henry 
Hub market and winter price is respectively 5.4 USD. In terms of cubic meters, we get the summer price of 170 USD and winter price of 194 USD per 1000 cubic meters. Thus, the average seasonal difference of prices for the last several decades on Henry Hub market approximately equalled 24 USD. This also means that by the end of the winter season the price is reduced by $12,4 \%$, and during autumn season it's being increased by $14.1 \%$ [14].

Let's consider the geographic location of gas storage facilities in Ukraine. To simplify the calculation of the optimization model, all gas storage facilities (total capacity of 31 billion cubic meters) were grouped according to their geographical location: i) West gas storage (capacity of 20.9 billion cubic meters); ii) Southwest gas storage (capacity of 4.5 billion cubic meters); iii) North gas storage (capacity of 3.1 billion cubic meters); iv) East gas storage (capacity of 2.5 billion cubic meters).

Further the total capacity of each gas storage group will be related to the main consumption regions: i) West gas storage (Lviv, capacity of 25.4 billion cubic meters); ii) North gas storage (Kyiv, capacity of 3.1 billion cubic meters); ii) East gas storage (Kharkiv, capacity of 2.5 billion cubic meters).

In order to solve the optimization model it is necessary to have some data about the cost of natural gas storage. Let us formulate the optimization model of natural gas supply which include the gas storage system and price difference in summer and winter periods.

At first denote: ${ }^{j}$ - index of natural gas supply region, $\mathrm{j}=1, \ldots, \mathrm{m}$ (external and internal sources all together); $i$ - index of natural gas consumption region, $\mathrm{i}=1, \ldots, \mathrm{n} . D_{i}$ - volume of the natural gas which was consumed in i region ( $D=\sum_{i=1}^{n} D_{i}$ - total consumption); $d_{i j}$ distance from $\mathrm{j}$ supplier to i consumer (measured in 100 kilometres); $\rho_{\mathrm{ji}} ; \mu_{j i}$ - matrices of natural gas supply volumes from $\mathrm{j}$ supplier to $\mathrm{i}$ consumer during summer and winter seasons respectively (measured in 1000 cubic meters); ${ }^{p_{0}}$ - transportation cost of natural gas (measured in USD for 1000 cubic meters per $100 \mathrm{~km}$.); $\mathrm{Pr}$ - natural gas price during summer season (in USD for 1000 cubic meters); $\mathrm{f}^{*} \mathrm{Pr}$ - natural gas price during winter season $(\mathrm{f}>1), \mathrm{Sl}$ - capacity of 1 gas storage facility $(\mathrm{l}=1, \ldots, \mathrm{k}) ; \Delta-$ natural gas storage cost (measured in USD for 1000 cubic meters during 6 months; $V_{j}-$ maximum volume of natural gas which can be provided by the $\mathrm{j}$ supplier.

During summer season gas storage facilities are considered as ordinary consumers and their consumption volumes are added to the total consumption but during heating season the same gas storage facilities can be already considered as suppliers and the stored natural gas can be added to other suppliers.

The supply of gas in the summer and the heating season are considered separately.

The objective function which has to be minimized consists of expenditure on purchasing, storage and natural gas transportation:

$$
W(\rho, \mu)=C_{d}(\rho, \mu)+C_{T}(\rho, \mu) \Rightarrow \min
$$

The cost of purchasing and storage can be stated as:

$$
C_{d}(\rho, \mu)=\operatorname{Pr} \sum_{i=1}^{n} \sum_{j=1}^{m} \rho_{j i}+f \cdot \operatorname{Pr} \sum_{i=1}^{n} \sum_{j=1}^{m} \mu_{j i}+(\operatorname{Pr}+\Delta) \sum_{j=m+1}^{m+k} \sum_{j=1}^{m} \mu_{j i}
$$

The last equation determines the cost of natural gas which was supplied directly to consumer's regions during the summer and heating seasons and the cost of natural gas stored in gas storage facilities for the next sixth months (the same level of price as it had been in summer, but also adding to it the cost of storage). 
Transportation cost:

$$
C_{T}(\rho, \mu)=p_{0} \sum_{i=1}^{n+k} \sum_{j=1}^{m} \rho_{j i} \cdot d_{j i}+p_{0} \sum_{i=1}^{n} \sum_{j=1}^{m+k} \mu_{j i} d_{j i}
$$

The first part of the equation (3) determines the transportation cost of the natural gas during summer period and the second part determines the same transportation cost but only for heating season.

There is block of constraints which is necessary for regional volumes of consumption and maximum storage capacity of gas storage facilities:

$$
\begin{aligned}
& \sum_{j=1}^{m}\left(\rho_{j i}+\mu_{j i}\right)+\sum_{j=m+1}^{m+k} \mu_{j i} \geq D_{i} ; i=1,2, \ldots, n \\
& \sum_{j=1}^{m} \rho_{j, m+l} \leq S_{l} ; l=1,2, \ldots, k \\
& \sum_{i=1}^{n} \mu_{l i} \leq \sum_{j=1}^{m} \rho_{j l} ; l=1,2, \ldots, k \\
& \sum_{i=1}^{n+k} \rho_{j i}+\sum_{i=1}^{n} \mu_{j i} \leq V_{j} ; j=1,2, \ldots m
\end{aligned}
$$

The first constraint (4.1) means that supply from primary suppliers and storage facilities have to satisfy the consumption volumes of each region. The second constraint (4.2) means that storage facilities cannot hold volume of natural gas which exceeds their maximum capacity. The third constraint (4.3) means that natural gas supply from storage facilities doesn't have to exceed the volume of injected natural gas. The last constraint (4.4) means that each supplier can't exceed its own export limits.

Besides this there is a need to include a natural constraint concerning consumption ratio during summer and heating periods. At the first phase it was considered that summer consumption equals $40 \%$ of total annual one and heating period consumption has the other $60 \%$. The full list of natural gas suppliers on the west border of Ukraine is given in table 1 .

At first let's consider merely the effect of geographic diversification of gas supply. To eliminate the price factor let's give each of the suppliers the same price. In this formulation of the optimization, it's advisable to add Russia as one of the suppliers. There are two possible solution of the model:

Monopolized gas supply from Russia, at the price of 220 USD for 1000 cubic meters; Objective function $=14.807$ billion USD; Purchasing cost 8.474 billion USD; Transportation cost $=6.333$ billion USD.

Gas supply only from EU countries (table 1), at the price of 220 USD for 1000 cubic meters; Objective function $=8.102$ billion USD; Purchasing cost 8,474 billion USD; Transportation cost $=2.762$ billion USD.

These calculations show the positive effect of reducing Transportation cost from natural gas supply diversification. The result of natural gas supply optimization in prices of 2016 including storage facilities is presented in table 1. The upper part of the table corresponds to the gas supply during the summer period, the lower part represents gas supply during heating period. 
Table 1. Matrix of natural gas supply in2016 prices o including storage facilities, billion cubic meters*

\begin{tabular}{|c|c|c|c|c|c|c|c|c|c|}
\hline & 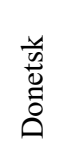 & $\stackrel{\vec{\Delta}}{\vec{\Delta}}$ & 蚉 & 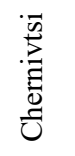 & 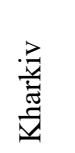 & 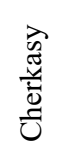 & $\begin{array}{l}n \\
\dot{s} \\
3 \\
3\end{array}$ & $\begin{array}{l}n \\
\hat{E} \\
\hat{0} \\
\dot{Z}\end{array}$ & $\begin{array}{l}n \\
\hat{E} \\
\tilde{E} \\
\text { in }\end{array}$ \\
\hline Drozdovichi & & 2.93 & 2.22 & & & & & & \\
\hline \multicolumn{10}{|l|}{ Uzhhorod } \\
\hline Beregove & & & & 1.32 & & 1.30 & 5.26 & & \\
\hline Chernivtsi & & & & & & & 4.00 & & \\
\hline Poltava & 0.60 & & & & 0.63 & 1.14 & & 4.11 & 1.52 \\
\hline Kharkiv & & & & & 3.07 & & & & \\
\hline \multicolumn{10}{|l|}{ Drozdovichi } \\
\hline \multicolumn{10}{|l|}{ Uzhhorod } \\
\hline \multicolumn{10}{|l|}{ Beregove } \\
\hline \multicolumn{10}{|l|}{ Chernivtsi } \\
\hline \multicolumn{10}{|l|}{ Poltava } \\
\hline Kharkiv & & & & & 4.93 & & & & \\
\hline West, s & & 3.95 & 3.32 & 1.99 & & & & & \\
\hline North, $\mathrm{s}$ & & 0.45 & & & & 3.66 & & & \\
\hline South, s & 0.90 & & & & 0.62 & & & & \\
\hline
\end{tabular}

*(natural gas supply during winter season is denoted by bold numbers, groups of gas storage facilities denoted by letter "s")

Objective function $=8.71$ billion USD. Purchasing cost $=6.01$ billion USD. Transportation cost $=2.70$ billion USD. According to the optimization model 14.9 billion cubic meters of natural gas have to be pumped into the storage facilities. The West group of storage facilities has to be filled in with 9.26 billion cubic meters, the North group with 4.11 billion cubic meters and East group with 1.52 billion cubic meters. It should be noted that during winter season almost all gas supply was performed from storage facilities except Kharkiv region where natural gas was taken from the domestic producer.

Let's compare the result of optimization model in prices of 2016 which include storage facilities with the result of the same optimization but without including storage facilities (table 2). Prices in both models were taken at the same level.

Objective function in case of not using storage facilities equalled 11.71 billion USD; the purchasing cost equalled 9.54 billion USD and transportation cost was 2.17 billion USD. In this case the price difference was taken at the level of $14 \%(\mathrm{f}=1.14)$. Comparing the obtained objective functions of both optimization models prove the advantage of gas storage using.

Table 2. Matrix of natural gas supply in prices of 2016 without including storage facilities, billion cubic meters*

\begin{tabular}{|l|l|l|l|l|l|l|}
\hline & Donetsk & Kyiv & Lviv & Chernivtsi & Kharkiv & Cherkasy \\
\hline Drozdovichi & & 2.93 & 2.22 & & & \\
\hline Uzhhorod & & & & & & \\
\hline Beregove & & & & 1.32 & & \\
\hline Chernivtsi & & & & & & \\
\hline Poltava & 0.60 & & & & 1.25 & 2.44 \\
\hline Kharkiv & & & & & 2.45 & \\
\hline
\end{tabular}




\begin{tabular}{|l|l|l|l|l|l|l|}
\hline Drozdovichi & & & $\mathbf{3 . 3 2}$ & & & \\
\hline Uzhhorod & & & & & & \\
\hline Beregove & & $\mathbf{4 . 4 0}$ & & & & $\mathbf{0 . 1 6}$ \\
\hline Chernivtsi & & & & $\mathbf{1 . 9 9}$ & & $\mathbf{0 . 6 9}$ \\
\hline Poltava & $\mathbf{0 . 9 0}$ & & & & & $\mathbf{2 . 8 1}$ \\
\hline Kharkiv & & & & & $\mathbf{5 . 5 5}$ & \\
\hline
\end{tabular}

*(natural gas supply during winter season is denoted by bold numbers)

A similar comparison was made for the gas supply in prices of 2017. Since the average weighted price of 2017 (table 3) was significantly lower than the price of 2016 $\overline{\operatorname{Pr}}_{2016}=269 U S D / 1000 \mathcal{M}^{3} ; \overline{\operatorname{Pr}}_{2017}=196 U S D / 1000 \mathcal{M}^{3}$, both objective functions of 2017 had lower values then in 2016.

Table 3. Import of natural gas to Ukraine from different countries in 2017

\begin{tabular}{|l|l|l|l|}
\hline Country & $\begin{array}{l}\text { Import, billion } \\
\text { cubic meters }\end{array}$ & $\begin{array}{l}\text { Import cost, million } \\
\text { USD }\end{array}$ & $\begin{array}{l}\text { Price USD/ 1 тис. } \\
\text { м3 }\end{array}$ \\
\hline Germany & 3.700 & 847.8 & 229.1 \\
\hline Poland & 1.500 & 343.2 & 228.8 \\
\hline France & 1.020 & 237.9 & 233.2 \\
\hline United Kingdom & 0.542 & 127.3 & 234.9 \\
\hline Hungary & 0.768 & 178.9 & 232.9 \\
\hline Czech Republic & 0.252 & 55.6 & 220.6 \\
\hline Slovakia & 0.222 & 55.3 & 249.1 \\
\hline Luxembourg & 0.179 & 40.7 & 227.4 \\
\hline Italy & 0.067 & 15.9 & 237.3 \\
\hline Austria & 0.048 & 11.2 & 233.3 \\
\hline Domestic producer & 20.500 & - & 179.6 \\
\hline
\end{tabular}

Including storage facilities into optimization model has significant benefits. The value of objective function in case of using storage facilities is less than in case of its absence ( 7.6 and 9.2 billion USD respectively). The main factor which defines the cost difference is that purchasing cost of natural gas in case of using storage facilities is less by 1.5 billion USD although the transportation cost is 0.5 billion USD more. Just like in case of 2016, 14.9 billion cubic meters were pumped into the gas storage facilities, but the volumes of the pumped in natural gas differ for different groups of storage facilities. The next question arises: "How in real world volumes of purchased natural gas will differ from optimized values?"

Volume of available natural gas in storage facilities at the beginning and end of winter season allows us to estimate the volume of natural gas which was pumped out from the storage facilities of Ukraine (fig. 2). The average level of natural gas consumption at the time interval of 2006-2016 was 12.7 billion cubic meters, the maximum consumption during these years was 16.9 billion cubic meters and the minimum consumption was 8.5 billion cubic meters. The volume of not used natural gas in storage facilities after winter season in average equals 9.7 billion cubic meters but during the last years its level decreased to 6 billion cubic meters, which at present time can satisfy national consumption for approximately two months. Significant natural gas residue leads to efficiency decreasing of storage facilities using however in case of gas shortages during heater season possible losses will be essentially 
higher. The possibility of such situation was shown by winter season of 2017-2018 when the rapid decrease of stored gas led to restrict of consumption.

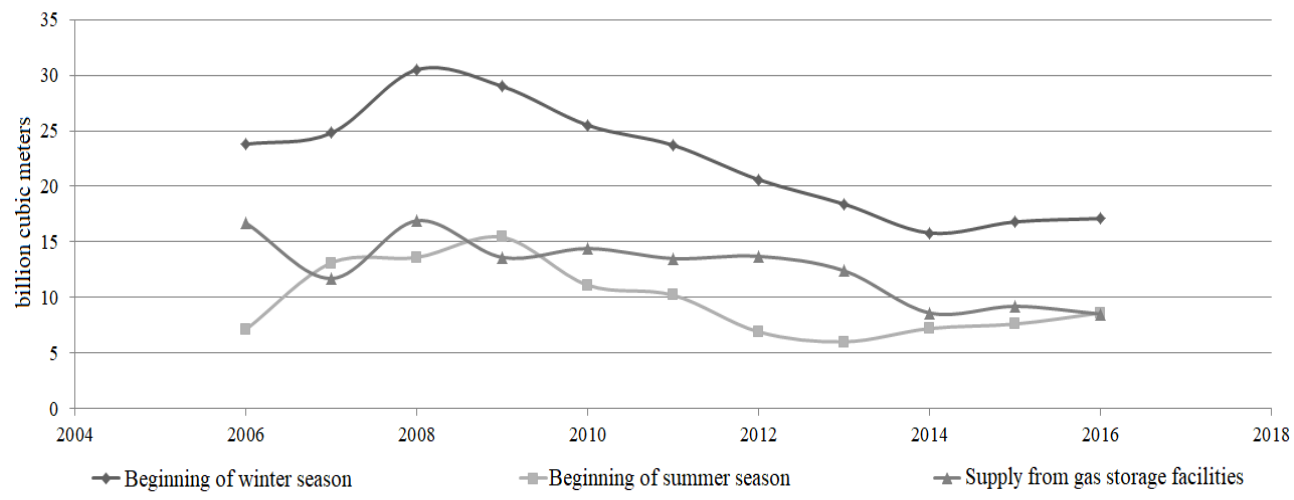

Fig. 2. Stored natural gas in storage facilities, 2000-2017

In any case, practically a double decrease of pumped natural gas in storage facilities, which had been taking place during recent years, indicates the incomplete use of existing opportunities to receive dividends from availability of storage facilities. It should be noted that calculated volume of used natural gas from gas storage facilities during heating season equals 14.9 billion cubic meters and is approaching the average level of gas supply from storage facilities during winter season (12.7 billion cubic meters) on the time range of 20062016. Optimal volumes of consumed natural gas were obtained under assumptions that consumption of natural gas during winter season equals $60 \%$ of annual level and winter prices are on $14 \%$ higher. Certainly, there may be other ratios of natural gas consumption and prices which lead to different optimal volumes of stored natural gas (Table 4).

Table 4. Different optimal solutions of the optimization model which include gas storage facilities, calculated on the data of $2016^{*}$

\begin{tabular}{|l|l|l|l|l|}
\hline & $5 \%$ & $10 \%$ & $15 \%$ & $20 \%$ \\
\hline $50 \%$ & 1) 7.60 & 1) 7.63 & 1) 7.67 & 1) 7.70 \\
& 2) 5.03 & 2) 5.06 & 2) 5.10 & 2) 5.13 \\
& 3) 12.66 & 3) 12.66 & 3) 12.66 & 3) 12.66 \\
\hline $55 \%$ & 1) 7.57 & 1) 7.61 & 1) 7.65 & 1) 7.69 \\
& 2) 4.98 & 2) 5.02 & 2) 5.06 & 2) 5.10 \\
& 3) 13.77 & 3) 13.77 & 3) 13.77 & 3) 13.77 \\
\hline $60 \%$ & 1) 7.54 & 1) 7.59 & 1) 7.63 & 1) 7.68 \\
& 2) 4.94 & 2) 4.99 & 2) 5.03 & 2) 5.07 \\
& 3) 14.89 & 3) 14.89 & 3) 14.89 & 3) 14.89 \\
\hline $65 \%$ & 1) 7.52 & 1) 7.57 & 1) 7.62 & 1) 7.67 \\
& 2) 4.90 & 2) 4.95 & 2) 5.00 & 2) 5.04 \\
& 3) 16.00 & 3) 16.00 & 3) 16.00 & 3) 16.00 \\
\hline $75 \%$ & 1) 7.48 & 1) 7.54 & 1) 7.60 & 1) 7.66 \\
& 2) 4.89 & 2) 4.95 & 2) 5.01 & 2) 5.07 \\
& 3) 18.23 & 3) 18.23 & 3) 18.23 & 3) 18.23 \\
\hline
\end{tabular}

Source: own calculation

Horizontal line represents percentage of price rising during winter season. Vertical line represents the share of natural gas which is being consumed during winter season. Main elements of the table:

1) Objective function, billion USD; 
2) Cost of purchased natural gas, billion USD;

3) Volume of used natural gas from gas storage facilities, billion cubic meters

Available gas storage facilities have a significant effect on the reduction of the objective function (cost of natural gas supply). It reduces the impact of rising prices during winter season.

But even at $20 \%$ of price rising and $75 \%$ of consumption rising during the winter season the maximum loading of gas storage facilities (18.2 billion cubic meters) doesn't exceed $60 \%$ of their total capacity. Access to gas storage facilities is so called damper of the excessive variability of the main financial indicators: transportation cost and cost of purchasing. In order to prove this statement, the estimations of natural gas price variance and variation coefficients, cost of purchased natural gas and volumes of its consumption from storage facilities for different combinations of price rising and volumes of consumed gas during winter season were made (table 5).

Table 5. Descriptive statistics of various optimal solutions for optimization model which include storage facilities

\begin{tabular}{|l|l|l|l|}
\hline & $\begin{array}{l}\text { Objective function, } \\
\text { billion USD }\end{array}$ & $\begin{array}{l}\text { Cost of purchased } \\
\text { natural gas, } \\
\text { billion USD }\end{array}$ & $\begin{array}{l}\text { Volume of natural gas } \\
\text { in storage facilities, } \\
\text { billion cubic meters }\end{array}$ \\
\hline Average value & 7.610 & 5.016 & 15.110 \\
\hline Variation & 0.004 & 0.004 & 3.866 \\
\hline Standard deviation & 0.060 & 0.066 & 1.966 \\
\hline $\begin{array}{l}\text { Coefficient of } \\
\text { variation, \% }\end{array}$ & 0.800 & 1.300 & 13.000 \\
\hline
\end{tabular}

Based on the obtained data it can be said that the largest variability is observed for optimal volumes of pumped in natural gas. Other parameters of objective function and purchasing cost stay almost unchanged: maximum value of variation coefficient for purchasing cost is $1.3 \%$, while for optimal volume of stored natural gas it exists at the level of $13 \%$.

In recent years, the significant reduction of natural gas consumption in Ukraine has been taking place, as it was mentioned this happens due to political and macroeconomic factors.

To the end of 2018 IMF recommends to raise the price of natural gas for population ones. That's why it's necessary to estimate volumes of consumed natural gas after price rising in order to calculate the optimal value of gas storage facilities loading. For accomplishing this estimation, the time series (1998-2017) of natural gas prices and volumes of its consumption by population were used.

\section{Conclusions}

Overall, in recent years, there has been a tendency toward decreasing of the natural gas prices difference on various regional markets. The variance of the average weighted global natural gas price can be considered as one of the main indicators of global natural gas market formation. The variance has significantly decreased during recent years, which also improves the possibilities of gas supply diversification for each importer of natural gas.

Quantitative experiments of solving the optimization model of natural gas supply in Ukraine with the condition that all suppliers have the same price confirmed the efficiency of the natural gas supply diversification, which have to be continued in the future by the efforts of Ukrainian diplomacy. These experiments revealed a significant impact of the natural gas storages availability on minimizing total cost of purchased natural gas. Due to the growth of pumped into gas storage facilities volumes of natural gas it became possible to maintain 
practically a stable level of gas supply cost (even under condition of significant rising of natural gas price and consumption during winter season).

With the help of econometric methods of time series analysis, an estimation of the elasticity of natural gas consumption by the population according to the price level was made (demand turned out to be inelastic according to the price level; the elasticity value equals $\mathrm{E}$ $=-0.24)$. On the basis of the calculated elasticity the estimation of the total consumption was also obtained. Including Odessa hub (LNG from Qatar) to the model as one of the supplies significantly reduces the cost of gas supply. Therefore, effective external economic steps toward achieving transit agreement with Turkey have to be made. Besides this agreement opens up prospects of natural gas re-export to Eastern European countries from Ukrainian gas storage facilities

\section{References}

1. T. Shindina, J.Streimikis, Y.Sukhareva, Ł. Nawrot, Economics and Sociology, 11(2), 334-344 (2018)

2. A.Skripnik, Energy sector of Ukrainian economy from the perspective of social prosperity (2017)

3. M. Tvaronavičienė, D. Prakapienė, K. Garškaitė-Milvydienė, R. Prakapas, Ł. Nawrot, Economics and Sociology, 11(1) (2018)

4. A. Frank, P. Osmundsen, M. Sandsmark, Energy Journal 27(2) (2006)

5. S. Amir, N. Das, O. Langhelle, Jo. Roy, M. Assadi, Energy Science \& Engineering, 7(4), 1075-1094 (2019)

6. A. Skrypnyk, N.Klymenko, M. Talavyria, A. Goray, Y.Namiasenko, International Journal of Energy Sector Management,14 (2), 468-481 (2019)

7. D. Zherlitsyn, A. Skrypnyk, N. Rogoza, S.Saiapin, T.Kudin, Estudios de Economia Aplicada, 2021, 38(4), 3994 (2021)

8. A. Skrypnyk, Y. Namiasenko, O. Sabishchenko, International Journal of innovative technologies in economy, 1 (13), 120-128 (2018)

9. Gas Balances in Ukrainian Underground Storages, https://naftogazeurope.com/article/en/englstorage (2018)

10. J.Haverkamp, Lifetime extension of ageing nuclear power plants: Entering a new era of risk, (2014)

11. O. Dyachuk, M. Chepelev, R. Podolets, G. Trypolska, Ukraine's transition to renewable energy by 2050 (2017)

12. V.Kadiyevskyy, N.Klymenko, Actual Problems of Economics, 152(2), 313-320 (2014)

13. A.Skrypnyk, O. Zhemoyda, N.Klymenko, L.Galaieva, T. Koval, Journal of Ecological Engineering, 22(3), 275-288 (2021).

14. A. Kaminskyi, M. Nehrey, M., International, Journal of Industrial Engineering and Production Research, 31(4), 579-586 (2020)

15. B.Fladmark, G.Grimstad, Seasonality in Natural Gas (2013)

16. World Energy Outlook 2020, https://www.iea.org/reports/world-energy-outlook-2020\# (2020)

17. K. Rosendahl, Special Issue of The Energy Journal, 57-69, (2009)

18. C. Corinne, A. Creti, B., Energy Policy, 36(11), 4235-4246 (2008)

19. A. Neumann, Special Issue of The Energy Journal, 187-199 (2009)

20. F.Holz, C.Kemfert, A Strategic Model of European Natural Gas Supply (GASMOD) (2016)

21. H. Hecking., T.Panke, EWI Working Paper,12(06), 5-11 (2012)

22. S. Catalan, Determinants of demand for natural gas and liquefied natural gas (2016) 